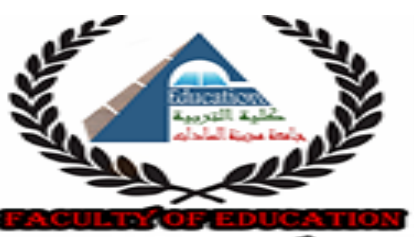

The Effect of a Mobile Learning-Based Program on Developing Some EFL Reading Skills and Enhancing Motivation towards Reading among Faculty of Education Sophomores.

By:

Eman Aly El-Sayed Diyyab 


\section{Abstract \\ The Effect of a Mobile Learning-Based Program on Developing Some EFL Reading Skills and Enhancing Motivation towards Reading among Faculty of Education Sophomores. \\ By: Eman Ali El-Sayed Diyyab}

Supervisors: 1. Dr. Adel T. Ibrahim

2. Dr. Gamal M. Shehata

The aim of the present study was to investigate the effect of using a mobile learning-based program on developing some EFL reading skills and enhancing motivation towards reading among faculty of education sophomores. The study participants were sixty second year, English section students at Faculty of Education, Sadat City University. The participants of the study were divided into two main groups (experimental and control). The participants of the experimental group were taught using the mobile learning-based program while the participants of the control group received regular instruction. The instruments of the present study were an EFL reading test with a rubric for assessing the participants EFL reading skills and an EFL reading motivation scale to determine the participants' reading motivation in EFL reading class. Having administering the study instruments, the findings of the present study revealed that the mobile learning-based program proved to have a great positive effect on the development of EFL reading skills and enhancement of motivation towards reading among faculty of education sophomores.

Key words: Mobile learning - Reading skills - Reading motivation. 


\section{Introduction}

In English as a foreign language (EFL) classes reading skills are considered critical to students' academic and future success .That is because EFL students are always measuring their success in English language learning by their ability to read effectively. They are expecting to be able to read efficiently in English sooner or later. Lyutaya (2013:27) ${ }^{1}$ highlighted that reading skills are especially vital in the EFL context, as reading is very often considered the only source of comprehensible and meaningful linguistic input that helps unconscious acquisition of the language. Stoller, Anderson, Grabe and Komiyam (2013:3) also pointed out that many students these days are struggling to become better readers. They want to be able to read and comprehend textbooks, journals in English, and access information on the internet. They added that good readers, at a minimum, need to be able to identify main ideas and details; distinguish between facts and opinions; draw inferences; determine author intent; summarize; synthesize two or more reading passages; and extend textual information to new tasks, such as oral presentations.

Hence, as previously demonstrated, reading cannot just be considered a simple skill; it is a highly cognitive skill that requires various operations. Flemming (2005) supported this view, indicating that reading is a process that has sub-processes which include perceptual, linguistic, and conceptual skills, convergent thinking skills (such as making generalizations) and divergent thinking skills (such as making implications and applications of information). Moreover, it includes strategic thinking, interpretations of linguistic symbols, inferring,

\footnotetext{
${ }^{1}$ The in-text citations and the references in the present study were formed according to the APA style, the $4^{\text {th }}$ edition.
} 
problem-solving, evaluation, and all forms of critical and creative thinking skills.

Accordingly, in EFL classes, reading skills are forming a fundamental part of language proficiency that affects academic success among university students. Sidek (2012:2) illuminated that the ability to read efficiently is considered one of the most important skills that university students of English as a foreign language need to acquire for their future success. University students are supposed to learn how to be fluent and proficient readers. They should be aware of a repertoire of reading strategies and the ability to apply them before, during, and after interacting with texts in meaningful combinations. Awareness of those reading strategies that help student-readers understand the text is essential for reading success.

When student-readers successfully apply reading strategies in EFL clsses, they will change the way they think and learn and no doubt, they will master EFL reading skills. As pointed out by Salataci and Akyel (2002), the goal of all reading instruction is to help students become expert strategic readers who can use strategies effectively to construct meaning. Strategic readers have purposes for their reading and adjust their reading to each purpose for each reading task. When the studentreader develops a general knowledge about what reading strategies are and why they are of a huge importance and how to apply them in reading activities, he/she becomes a strategic reader. Wilhelm, Baker and Dube (2001) concluded that strategic reading is neither teacher-centered nor student-oriented but a learning -centered instructional practice that engages students in purposeful learning process. It was added that strategic reading teaches students to use comprehension strategies while working cooperatively. 
Based on what was stated previously, strategic student-readers can gradually start to judge the quality, truth, validity, accuracy or worth of the reading material in terms of criteria and standards that they have formulated from their prior background knowledge. According to (ElMarsafy, 2009; Kennedy, 2001) student-readers must be aware that nothing is automatically true just because it is in print or on the web. They have to develop the ability to read critically. Based on such criteria the ideas included in the reading materials are accepted or rejected. Judging what is read and explaining why is called critical reading. It depends on making personal opinions about the reading material through reacting with the text and justifying this reaction on the basis of certain valid criteria that the reader has formed out of his/her prior knowledge or experience.

Thus, critical-readers should apply their own prior background knowledge or experience along with their critical thinking skills in order to be able to understand and criticize the reading texts. They should at least be capable of distinguishing between facts and opinions and relevant and irrelevant information. Student-readers should also be aware that critical reading does not mean to search only for weaknesses and negative points all the time. Rather, critical readers should learn how to be able to assess the reading material illustrating its strengths and weaknesses. Thus, good critical readers should be able to present strong evidence that can justify their own views along with showing reasonable illustrations and discussions that enhance their own implications. Furthermore, when a critical reader shifts from criticizing reading materials to producing something new and creative about these materials, he/she becomes a creative reader. (El-Marsafy: 2009). Creative readers can always invent and produce different and new things and parts that suit the reading materials. Rivers (2001) indicated that creative readers are those who are 
sensitive to the problems and missing information or even divergent items in the text.

Consequently, the importance of EFL reading skills and their vital role in developing English language acquisition has become widely recognized. Rabbidge and Lorenzutti (2013:29-30) demonstrated that the reading classes should focus as much as possible on providing students with various learning opportunities that can help them experience reading in English as less stressful and more enjoyable. Thus, enhancing reading motivation among the student-readers will allow students to respond reflectively, emotionally and naturally to the content. Ciampa (2012:34) clarified that the constructivist theory claims that knowledge is actively constructed by the learner for learning depends on the learner's internal drive, goals, beliefs and attitudes towards any reading material. All these factors affect the readers' comprehension of any reading material. Accordingly, reading motivation variables such as: choice, curiosity, feedback, personal interest, and involvement are very necessary to enhance reading achievement.

Thus, it may be impeded that one of the most essential aims of teaching English as a foreign language is developing EFL reading skills and enhancing motivation towards reading among faculty of education students. Reading is a completely individual activity in which faculty of education students at the same course may be reading at different levels and applying different reading strategies. However, it seems quite difficult for EFL instructors to teach their students individually in reading classes, because instructors do not have time to devote their attention to each student in turn, in addition to the problem of offering and creating adequate teaching formats that suit the students' different attitudes and paces. Hence, in order to overcome such difficulties and improve such 
reading classes, a mobile learning (m-learning) solution has been greatly suggested and focused on in recent years, for its pedagogical richness, flexibility and effectiveness.

M-learning approach is related to several theories such as Behaviorism, Cognitivism, Constructivism, Situated Learning, ProblemBased Learning, Context Awareness Learning, Socio-Cultural Theory, Collaborative Learning, Conversational Learning, Lifelong Learning, Informal Learning, Activity Theory, Connectivism, Navigationism as well as Location-based learning (Keskin \& Metcalf, 2011: Serin 2012). All these theories stressed that all students are different. They learn in different ways and at different paces. Consequently, personalized learning has become a must. In the same time, interaction is vital for a learner in the edge of learning as it helps him/her enhance his/ her learning achievement. Interaction between the learner and other more skillful peers could effectively aid in developing the learner's skills and strategies. (Abdullah, Hussin, Asra, \& Zakaria, 2013:218). In this context m-learning seems to be the ideal solution because reading courses may include cooperative language activities where skillful peers could help less competent readers to achieve proximal development.

Since the beginning of the $21^{\text {st }}$ century, with the introduction of mobile devices, the use of the concept m-learning has become frequent. Nowadays, mobile devices are among the new technologies because of giving the user more freedom in time and space. M-learning refers to the use of mobile or wireless devices and technologies such as (cell phones, smart phones, palmtops, handheld computers, tablets, laptops, and personal media players) for educational purposes that promote flexibility and mobility of the educational process. It is an approach in which learners take primary responsibility and control of their learning process 
including setting goals and evaluating outcomes. (Park, 2011:79: Pilar, Jorge, \& Cristina, 2013:1).

Moreover, Korkmaz (2015:1) added that mobile devices have become very advantageous when compared with desktop computers because learners can be in constant motion and an important part of learning takes part out of school. Thus, students will be engaged with learning activities in different physical environments. Besides, m-learning supports group work and improves communication and cooperative learning. Further, Reinders (2010:20) emphasized that m-learning supports learning in language classes as it comes with ever-increasing functions that most students are adept at using. It was highlighted that most activities related to language learning will work with most mobile phones and do not require special knowledge or additional software or hardware.

\section{Pilot study}

In spite of the importance of EFL reading skills for EFL students, a lack of EFL reading skills among faculty of education students is clearly noticed. Moreover, EFL reading skills do not receive the required attention and interest in reading classes. To document the study problem, a pilot study was conducted to find out the students' difficulties in EFL reading skills. The pilot study consisted of three parts:

The first part dealt with the students' EFL reading skills. An EFL reading test (appendix 1) was administered to a sample of second year university students $(\mathrm{N}=30)$ enrolled in the English section at Faculty of Education, Sadat City University at the second semester of the academic year 2014-2015, and it was found that they encountered serious difficulties in reading classes. 
The second part of the pilot study was a content analysis of the reading course used for Faculty of Education, English section sophomores (appendix 2). It was found out that the Reading" textbook placed a great deal of emphasis upon some reading comprehension strategies and critical reading skills. However, it did not focus on any creative reading skills. Besides, it did not present a classification of the reading strategies for the students. Moreover, there were no activities that could enhance motivation towards reading among the student-readers.

The third part of the pilot study dealt with students' motivation towards reading. The present study researcher interviewed a sample of second year university students $(\mathrm{N}=30)$ enrolled in English section at Faculty of Education, Sadat City University at the second semester of the academic year 2014-2015.. The findings indicated that the majority of the students had a poor level in motivation towards reading (appendix 3 ).

\section{Statement of the Problem}

The problem of the current study was the poor level of EFL faculty of education sophomores in reading skills and reading motivation. That is why the current study attempted to develop Faculty of Education sophomores' reading skills and enhance their motivation towards reading.

\section{Questions of the Study}

The present study was an attempt to answer the following questions:

1- To what extent do EFL faculty of education sophomores master EFL reading skills?

2- What is the level of EFL faculty of education sophomores in motivation towards reading?

3- What are the features of the mobile learning-based program? 
4- To what extent does the suggested mobile learning-based program develop some EFL reading skills among EFL faculty of education sophomores?

5- To what extent does the suggested mobile learning-based program enhance EFL faculty of education sophomores' reading motivation?

\section{Significance of the Study}

The significance of the present study was presented in what it offered to the following groups:

As for the second year faculty of education (English section) students:

- Developing some EFL reading skills.

- Encouraging and motivating them to read.

As for EFL instructors:

- Helping and encouraging them to seek for new learning methods and activities.

- Providing them with information about mobile learning approach that helps in developing their students' EFL reading skills.

For the designers of English language curricula:

- Providing them with a mobile learning-based program that can be of great importance in developing EFL reading skills and enhancing students' motivation towards reading.

\section{Delimitations and Scope of the Study}

This study was delimited to the following: 
1. Sixty EFL Faculty of Education sophomores at Sadat City University participated in the study.

2. Some EFL reading skills required for EFL faculty of education sophomores, such as (superficial and inferential skills, critical skills and creative skills).

3. The second semester of the academic year 2016/2017.

\section{Procedures of the Study}

The following procedures were followed to carry out the present study:

\section{Identifying the form of the mobile learning-based program through:}

a) Reviewing literature and previous studies related to mobile learning, EFL reading skills, and reading motivation.

b) Identifying objectives, activities, and methods of evaluation of the mobile learning-based program.

c) Modifying and setting the program in its final form.

\section{Identifying the EFL reading skills required for EFL faculty of} education, English section sophomores through:

a) Reviewing literature and previous studies related to EFL reading skills.

b) Preparing a checklist of EFL reading skills required for second year, English section student teachers, submitting the checklist to a jury to verify its validity and setting the checklist in its final form according to the jury's suggestions.

c) Developing an EFL reading test to be used as a pre- and posttest, submitting the test to a jury to verify its validity and setting the test in its final form according to the jury's suggestions. 
d) Preparing the EFL reading motivation, submitting the reading motivation scale to a jury to verify its validity and setting it into its final form according to the jury's suggestions.

e) Drawing the study participants of the second year (English section) Faculty of Education, Sadat city university students and dividing them into two main groups:

- The experimental group.

- The control group.

f) Applying the EFL reading test to the participants of the study before the implementation of the program, to measure their level in EFL reading skills and then, applying the reading motivation scale to the participants of the study before the implementation of the program, to measure their level in reading motivation.

\section{Identifying the effects of a mobile learning-based program on} developing EFL reading skills and enhancing motivation towards reading among faculty of education sophomores through:

a) Applying the program to the experimental group.

b) Using the traditional method to teach the control group.

c) Applying the EFL reading test to the participants of the study after the implementation of the program.

d) Applying the reading motivation scale to the study participants after the implementation of the program.

e) Comparing the findings statistically.

f) Analyzing and interpreting the findings of the study.

g) Recommendations and suggestions. 


\section{Participants of the Study}

The participants of the present study were sixty students enrolled in the second year, English Section, Faculty of Education, Sadat City University. They were divided into two groups, an experimental group $(\mathrm{N}=30)$ and a control one $(\mathrm{N}=30)$.

\section{Instruments and Materials of the Study}

The present study researcher prepared and used the following instruments and materials:

1. An EFL reading checklist.

2. An EFL reading test, with a rating scale to assess the study participants' performance.

3. A reading motivation scale.

4. A mobile learning-based program (MLBP).

5. A teacher's guide.

\section{Terminology}

The current study handled the following definitions:

\section{EFL reading skills}

Nunan (2004) pointed out that reading skills are defined as the learner's ability to comprehend data in the reading text and fulfill an assigned task based on text information, via meaningful interaction. ElMarsafy and Abdel Haq (2009:51) defined reading skills as the ability to construct meaning by interacting with texts. Rashidi and Khosravi (2010:82) also defined reading skills as the ability to interact with the characteristics of the texts to construct meaning. 
In the present study, EFL reading skills are defined operationally as, EFL faculty of education sophomores' performance in choosing and applying the most suitable reading st6++rategies that can help comprehend, criticize and produce something new about the reading material whether it is a printed copy or an electronic one.

\section{Mobile learning}

Peter (2007) defines mobile learning as a useful component of the flexible learning model represent a subset of e- learning, a step toward making the educational process "just in time, just enough and just for me" (p. 15). Kadirire (2009) defines m-learning as a form of e-Learning, which can take place anytime, anywhere with the help of a mobile communication device such as a mobile phone, a personal digital assistant (PDA), iPod or any such small portable device. Traxler (2009:11-12) states that mobile learning exploits both handheld computers and mobile telephones and other devices that draw on the same set of functionalities. Park (2011:79) defines mobile learning as the use of mobile or wireless devices for the purpose of learning while on the move.

In the present study, mobile learning is defined operationally as, a pedagogical approach, used in EFL classes to emphasize the availability, portability, flexibility and mobility of the EFL learning process.

\section{Motivation towards Reading}

Motivation refers to "the likelihood of choosing one activity over another, as well as the persistence and effort exerted when participating in the chosen activity" (Malloy, Marinak, \& Gambrell, 2010, p.2). Ciampa (2012:2) defined reading motivation as, a factor in which students choose to devote their energy to an effortful reading activity. Moreover, 
Melekoglu and Wilkerson (2013:1) defined reading motivation as reading for pleasure.

In the present study, motivation towards reading is defined operationally as, the effort, persistence and likelihood of EFL faculty of education sophomores during an EFL reading course that promote and enhance the level of EFL reading comprehension and achievement.

\section{The Mobile Learning-Based Program (MLBP)}

For achieving the purpose of the study, a program based on the mobile learning approach was designed. The purpose of the program was developing some EFL reading skills and enhancing reading motivation among second year, Faculty of Education, Sadat City University sophomores.

\section{Goals of the MLBP}

By the end of the program, the students were expected to:

1. Identify the importance of the mobile learning-based program in EFL reading classes.

2. Realize the importance of EFL reading skills.

3. Benefit from the availability, flexibility and mobility of the mobile learning-based program.

4. Learn to work in pairs, groups and individually.

5. Comprehend the reading materials.

6. Be critical readers.

7. Creative readers.

8. Be highly motivated to read in English.

\section{Duration of the MLBP}

The program is intended to last for six weeks. In each week students have from two to three lessons. Each lesson presents specific skills. The time allocated for each lesson is 120 minutes. 


\section{Assessment of the MLBP}

To be effective, the MLBP must have an impact on students' reading skills. The assessment system would allow teachers and learners to measure the impact and effect of the program. The MLBP used two types of assessment, formative and summative; the first of these was formative assessment. Formative assessment was used for assessing the students' progress in EFL reading lessons. The students were provided by immediate positive feedback regarding their responses in pairs, groups, or individually. Various assessment techniques were used to determine the students' development throughout the program's lesson. Among these techniques are the following:

- The minute paper.

- The muddiest point paper.

- Self-correction paper.

- Peer correction paper.

- Teacher feedback.

- Student's reading logs.

\section{Implementation of the MLBP}

\section{Pre-assessment}

Before the implementation of the program, the EFL reading test and the EFL reading motivation scale were administered to the two groups of the study, the control group $(\mathrm{N}=30)$ and the experimental group $(\mathrm{N}=30)$. Pre-testing was achieved at the beginning of the second semester of the academic year 2016/2017. The means, standard deviation and " $t$ " value of the study sample were computed.

\section{Administration of the MLBP}

The MLBP was administered to the experimental group by the present study researcher and the control group was taught traditionally. The program lasted for six weeks with two or three lessons per week and each lesson lasted for about two hours. At the beginning of the program, the objectives, characteristics and importance of the program were illuminated to the study participants. At the beginning of each lesson, the participants were informed about the roles of the teacher and students, the instructional materials and various learning activities and procedures. At 
the end of each lesson, the present study researcher assigned the participants some electronic activities, related to what they had learnt in order to assure that they have mastered the skills of each lesson. At the end of the program, the participants' progress and development in EFL reading skills and EFL reading motivation were checked after the implementation of the MLBP using the EFL reading test and the EFL reading motivation scale..

\section{Findings of the Study}

This section dealt with the findings of the study in terms the study hypotheses.

\section{Hypotheses of the Study}

1. There is a statistically significant difference at the 0.01 level between the mean scores of the study participants of the experimental and control groups on the post-application of the EFL reading test in favour of the experimental group. The first hypothesis has three sub-hypotheses:

1.A There is a statistically significant difference at the 0.01 level between the mean scores of the study participants of the experimental and control groups in EFL reading superficial and inferential skills on the post-application of the EFL reading test in favour of the experimental group.

1. B There is a statistically significant difference at the 0.01 level between the mean scores of the study participants of the experimental and control groups in EFL critical reading skills on the post-application of the EFL reading test in favour of the experimental group.

1. C There is a statistically significant difference at the 0.01 level between the mean scores of the study participants of the experimental and control groups in EFL creative reading skills on 
the post-application of the EFL reading test in favour of the experimental group.

2. There is a statistically significant difference at the 0.01 level between the mean scores of the study participants of the experimental and control groups in the post-application of the EFL motivation scale in favour of the experimental group.

\section{Verifying Hypothesis (1)}

The first hypothesis states that "there is a statistically significant difference at the 0.01 level between the mean scores of the study participants of the experimental and control groups on the postapplication of the EFL reading test in favour of the experimental group". The following table presents the participants' mean scores, standard deviations, $t$-value and level of significance in the post-application of the EFL reading test.

Table 1: The participants' mean scores, standard deviations, $t$-value and level of significance in the post assessment of the EFL reading test.

\begin{tabular}{|c|c|c|c|c|c|c|c|c|}
\hline Group & No & Mean & S. D & D. F & F & Sig. & $\begin{array}{c}\text { t- } \\
\text { value }\end{array}$ & $\begin{array}{c}\text { Level } \\
\text { of sig. }\end{array}$ \\
\hline Control & 30 & 35.05 & 7.6 & & & $\begin{array}{c}\text { Not } \\
\text { sig. }\end{array}$ & 13.45 & 0.01 \\
\hline $\begin{array}{c}\text { Experime } \\
\text { ntal }\end{array}$ & 30 & 61.8 & 7.8 & 58 & 0.25 & & &
\end{tabular}

This table indicated that the mean scores of the study participants of the experimental group in the post application of the EFL reading test are higher than the scores of the study participants of the control group in the 
post-application of the same test. In addition, t-value is 13.45 which is significant at the 0.01 level. Thus, it was confirmed that the MLBP had a clear positive effect on the study participants of the experimental group. Consequently, the first hypothesis was confirmed.

\section{Verifying Hypothesis (2)}

The second hypothesis states that "there is a statistically significant difference at the 0.01 level between the mean scores of the study participants of the experimental and control groups in the post-application of the EFL motivation scale in favour of the experimental group". The following table presents the students' mean scores, standard deviations, $\mathrm{t}$ value and level of significance of the study participants of the control and experimental groups in the post-application of the EFL reading motivation scale.

Table 2: The participants' mean scores, standard deviations, t-value and level of significance in the post assessment of the EFL reading motivation scale.

\begin{tabular}{|c|c|c|c|c|c|c|c|c|}
\hline Group & No & Mean & S. D & D. F & F & Sig. & $\begin{array}{c}\text { t- } \\
\text { value }\end{array}$ & $\begin{array}{c}\text { Level } \\
\text { of sig. }\end{array}$ \\
\cline { 1 - 6 } Control & $\mathbf{3 0}$ & $\mathbf{4 0 . 7 7}$ & $\mathbf{3 . 6}$ & & & Not & & \\
Experimental & $\mathbf{3 0}$ & $\mathbf{6 1 . 5}$ & $\mathbf{2 . 9}$ & $\mathbf{5 8}$ & $\mathbf{0}$ & sig. & $\mathbf{2 4 . 4}$ & $\mathbf{0 . 0 1}$ \\
\hline
\end{tabular}

Accordingly, it was confirmed that there was a statistically significant difference at the 0.01 level between the mean scores of the study participants of the experimental group that was taught using the MLBP and the control group that was taught traditionally on the post-application of the EFL reading motivation scale in favour of the experimental group. Such development has occurred due to the use of the MLBP. 


\section{Discussion of the Findings of the Study}

The findings of the first hypothesis revealed that there was a statistically significant difference at the 0.01 level between the mean scores of the study participants of the experimental and control groups on the post-application of the EFL reading test in favour of the experimental group. As previously indicated, the participants of the experimental group showed more development in their EFL reading skills with its three levels of comprehension (superficial and inferential level, critical level and creative level) in the post assessment of the EFL reading test than the participants of the control group. The findings of the study illuminated that the t-value was significant at 0.01 level. Such development proved and supported the first hypothesis with its three sub-hypotheses statistically. This development was related as showed to the administration of the mobile learning-based program.

Moreover, the findings of the present study second hypothesis clarified that there was a statistically significant difference at the 0.01 level between the mean scores of the study participants of the experimental and control groups in the post-application of the EFL motivation scale in favour of the experimental group. Motivation towards reading was notably increased more among the participants of the experimental group. This increase was totally related to the administration of the mobile learning-based program.

\section{Conclusion}

The findings of the present study revealed that the experimental group participants' EFL reading skills were highly developed after the implementation of the MLBP. Besides, their motivation towards reading was highly enhanced and increased. Thus, the significant differences 
found in favour of the experimental group on the post assessment of the EFL reading test and the EFL reading motivation scale were directly related to the implementation of the MLBP which has proved to have a great positive effect on developing EFL reading skills and enhancing motivation towards reading among faculty of education sophomores. In the light of the delimitations and the findings of the present study the following conclusions can be impeded:

- The study participants of the experimental group showed a great development in the EFL reading skills with their three levels of comprehension; superficial and inferential, critical and creative level.

- The study participants of the experimental group showed an apparent enhancement in motivation towards reading, they became much more motivated and encouraged to read.

- The MLBP was found to have a clear positive effect in developing EFL reading skills and enhancing motivation towards reading among faculty of education sophomores.

Before, the implementation of the MLBP, most of the participants were found to have lack in their EFL reading skills and a clear shortage in motivation towards reading in EFL reading classes. They did not like EFL reading classes. Thus, they were passively engaged in the reading tasks and activities. They rarely read texts of their own interest. They did not cooperate with their peers in pair or group work during the EFL reading classes. Besides, they did not try to read outside the classroom or use their mobile devices for reading purposes. However, after the implementation of the MLBP, the participants of the experimental group achieved notable gains concerning EFL reading skills and motivation towards reading. These gains were attributed to the administration of the MLBP. The availability, flexibility and mobility of the mobile learning- 
based program helped each individual student reader learn according to his own pace, abilities and attitudes. The immediate positive feedback helped the student readers take personal commands over their own progress in EFL reading skills.

Consequently, the findings of the present study were found to be consistent with previous literature which clarified the positive effects of the MLBP on developing EFL reading skills and enhancing motivation towards reading among faculty of education sophomores. The next chapter was assigned for providing a brief summary of the present study.

\section{Recommendations}

Based on the findings of the present study, the following recommendations are suggested:

- The mobile learning-based program should be implemented in teaching EFL reading skills for faculty of education, English section students.

- More attention should be paid for the new approaches, strategies or techniques used in teaching EFL reading skills among faculty of education students.

- More attention should be paid to the students' motivation towards reading in EFL classes as it has a great effect concerning the development of EFL reading skills.

- Students should be encouraged to use their mobile devices for reading purposes inside and outside the EFL classrooms.

- Students' social behavior and cooperation with their peers should be given due attention in the Egyptian faculties of education.

- EFL instructors should assign out of class activities as well as in class activities to help EFL student readers read anytime and anywhere. 
- EFL instructor should apply various mobile learning strategies that enhance the development of superficial, literal, critical and creative reading skills.

- EFL instructors should apply various EFL reading strategies in EFL reading classes.

- Egyptian faculties of education should support mobile learning strategies and activities.

- Curriculum developers should supply mobile learning strategies and activities to EFL reading courses.

- EFL instructors should encourage their student readers to develop their critical and creative reading skills.

- Egyptian faculties of education should encourage the idea of establishing an EFL reading club for English sections.

\section{Suggestions for further Studies}

Replication of this study with modification is recommended. While it was the purpose of the study to investigate the effect of a mobile learningbased program on developing EFL reading skills and enhancing motivation towards reading among faculty of education sophomores.

1) Further research is needed to develop other language skills (listening, speaking and writing through the use of the mobile learning-based program.

2) Further research is needed with other student populations at different levels of education and in different locations of Egypt with the purpose of investigating the effect of a mobile learningbased program on developing EFL speaking skills and enhancing motivation towards reading. 


\section{References}

Abdullah, M. R., Hussin, Z., Asra, \& Zakaria, A. (2013). Mlearning scaffolding model for undergraduate English language learning: Bridging formal and informal learning. TOJET: The Turkish Online Journal of Educational Technology, 12(2), 217-233.

Ciampa, K. (2012). Reading in the digital age: Using electronic book as a teaching tool for beginning readers. CJLT RCAT, 38(2), 126.

El-Marsafi, A., \& Abdel Haq, M. E. (2009). New trends in teaching reading and writing: From theory to practice. Benha. Egypt: Middle East for Educational Services.

Fleming, L. E. (2005). Reading for results: SQ3R: A system for college reading. Boston. New York: Houghton Mifflin Company.

Kadirire, J. (2009). Mobile learning. In R. Goy (Ed), The evolution of mobile teaching and learning. California: Informing Science Press.

Kennedy, E. C. (2001). Methods in teaching developmental reading. U.S.A: Peacock Publishers Inc.

Keskin, N. O., \& Metcalf, D. (2011). The current perspectives, theories and practices of mobile learning. TOJET: The Turkish Online Journal of Educational Technology, 10(2), 202-208.

Korkmaz, O. (2015). New trends on mobile learning in the light of recent studies. Participatory Educational Research (PER), 2(1), 110. 
Lyutay, T. (2013). Reading logs: Integrating Extensive reading with writing tasks. English Teaching Forum, (1), 26-34.

Malloy, J. A., Marinak, B. A., \& Gambrell, L. B. (2010). Essential readings on motivation. Newark, DE: International Reading Association.

Melekoglu, M. A., \& Wilkerson, K. L. (2013). Motivation to read: How does it change for struggling readers with and without disabilities. International Journal of Instruction, 6(1), 1-12.

Nunan, D. (2004). Task-based language teaching. Cambridge:

Cambridge University Press.

Park, Y. (2011). A pedagogical frame work for mobile learning:

Categorizing educational applications of mobile technologies into four types. International Review of Research in Open and Distance Learning, 12(2), 2-25.

Peter, K. (2007). M-learning: Positioning educators for a mobile connected future . International Journal of Research in Open and Distance Learning, 8(2), 1-17.

Pilar, R., Jorge, A., \& Cristina, C. (2013). The use of current mobile learning applications in EFL. Procedia-Social and Behavioural Sciences, 103(2013), 1189-1196.

Rabbidge, M., \& Lorenzutti, N. (2013). Teaching story without struggle: Using graded readers and their audio packs in EFL classroom. English Teaching Forum, (1), 28-34

Rashidi, N., \& Khosravi, N. (2010). Assessing the role of depth and breadth of vocabulary knowledge in reading comprehension 
of Iranian EFL learners. Journal of Pan-Pacific Association of Applied Linguistics, 14(1), 81-108.

Reinders, H. (2010). Twenty ideas for using mobile phones in the language classroom. English Teaching Forum, (3), 20-33.

Rivers, W. M. (2001). Teaching foreign language skills. Chicago. U.S.A: University of Chicago Press.

Salataci, R.,\& Akyel, A. (2002). Possible effects of strategy instruction on L1 and L2 reading. Reading in Foreign Languages, 14(1).

Serin, O. (2012). Mobile learning perceptions of the prospective teachers( Turkish Republic of Northern Cyprus). TOJET: The Turkish Online Journal of Educational Technology, 11(3), 222-233.

Sidek, H. M. (2012). EFL reading instruction: communicative task-based approach. International Journal of Instruction, 5(2), 2-20.

Stoller, F. L., Anderson, N. J., Grabe, W., \& Komiyama, R. (2013). Instructional enhancements to improve students' reading abilities. English Teaching Forum, (1), 2-11.

Traxler, J. (2007). Defining, Discussing and Evaluating Mobile Learning: The moving finger writes and having writ... . The International Review of Research in Open and Distance Learning, 8(2), 1-12.

Wihelm, J. D., Baker, T. N., \& Dube, J. (2001). Strategic reading: Guiding students to lifelong literacy 6-12. London: Boyton Cook Publishers. 